\title{
Student abuse in medical colleges of Karachi, a descriptive Cross-sectional study.

\begin{abstract}
Background: Medical students are suspected to be the most compassionate, warm hearted and devoted students to their profession. In the process of cultivating future doctors any bad impact to their personalization may lead to a decrease in self-esteem, spirits and positive mood. Objective: The following study is conducted to make an estimation of different types of abuse that medical students are facing in Medical universities of Karachi. Furthermore, this study also intends to analyze which type of abuse is more prevalent and if the universities have a complaint department for taking a proper action against abuse or not. Material \& Methods: A descriptive cross sectional study was conducted in private and government medical colleges of Karachi, Sindh Pakistan, in the months of June and July 2014. Data collection was based on random data sampling comprising of 250 subjects, which included male and female students between the ages of 20-25 years. Results: According to our study's findings, about $47.47 \%$ of abuse is seen in medical colleges of Karachi. Among those who had faced bullying or harassment, $38.44 \%$ reported that they had experienced verbal abuse, $54.76 \%$ reported academic abuse, $6.9 \%$ faced physical abuse, and $18.56 \%$ faced sexual abuse. There was no reported harassment cell found in medical colleges of Karachi and hence, no one has ever taken authority. Conclusion: Therefore, it has been concluded that mistreatment and abuse are common occurrences in our medical colleges. This has found to be very adverse for learning, determination and the self-confidence of our medical students and for a futuristic personality of a doctor as well.
\end{abstract}

\section{Introduction}

Every year, thousands of students apply for admissions to medical colleges of Pakistan. Of them, less than only half of the students pack their luggage, uplift their dreams, and cross the realm of their home to be fortunate enough to start the uncertain journey of medical education in Pakistan (Pakistan Education Statistics; 201011). In a well-organized world of education, it is desired that the predictability of academic success is fairly higher than that of failure. However, academic accomplishment at the college level lacks such orderly qualities (Rau \& Durand; 2000). Through his study published in JAMA, Henry K. Silver was the first pediatrician to recount the rife of medical student harassment. (Silver, 1982). Mistreatment/abusive attempts or harassment during the course of study has always led to negative impact on students' life. The term harassment is defined as interpersonal behavior aimed at intentionally harming another person (Bowling \& Beehr; 2006). These attempts eventually disadvantage the person in studying, receiving education, conducting research, or performing their duties. Furthermore, it may cause mental and physical suffering that will inevitably hinder him or her from studying.

\section{Objective:}

- To evaluate harassment in medical colleges of Karachi.

- To inquire about the types of abuse faced by most participants.

- To find out whether universities have a complaint department, and whether they take actions against it or not.

\section{Rationale of the Study:}

Any kind of sexual or inter-personal harassment is prohibited at HEI (Higher Educational Institutions) and constitutes a punishable offense under HEC (Higher Educational Commission) policy. However, mistreatment of medical students has been eventually enhanced. We conducted a short survey of medical colleges to discover if there are any reporting authorities working for this major issue. Shockingly, most of the government and public sectors have not mentioned HEC guidelines even in their prospectus. However, it will speculate the significant aspects of student life in medical colleges and a platform to prove the actual happenings in the medical colleges, despite the fact that there is a law constituted.

Operational Definitions:
Harassment: It is defined any as interpersonal behavior aimed at intentionally harming another person.

Physical Abuse: It is generally defined as the presence of a nonaccidental and always intentional injury resulting from an act of commission

Academic Abuse: It is a violation of public rights by a university member who abuses his or her authority in an educational or research setting and speaks or acts improperly and unfairly to another member of their university.

Verbal abuse: It is a form of harassment that leaves no visible scars; however, the emotional damage to the inner core of the victim's self can be devastating.

Sexual harassment: It is defined as any unwelcome sexual advance, request for sexual favors or other verbal/physical conduct of a sexual nature. It can interfere with work and constitutes a condition of employment or creates an intimidating, hostile and offensive work environment.

\section{Methodology}

This is a descriptive cross sectional study. The study was carried out in the month of June and July, 2014. The study consisted of 250 subjects (ages 20-25) who specifically had pre-clinical and clinical designations. Each subject either lived in Karachi or was temporarily here for studies. The study was conducted at public and private medical colleges of Karachi, Sindh, Pakistan. Data collection was based on random data sampling, which was selected equally from private and public medical colleges of Karachi. The names of medical colleges are being withheld to preserve the anonymity of participants. Verbal consent was also taken The questionnaire consisted of two parts perceived mistreatment and reporting strategies. The mistreatment questionnaire was developed by the American Medical Association's Office of Education Research to gather information about the frequency, types, and sources of perceived mistreatment over the course of medical school for Verbal Abuse, Academic Abuse, Physical Abuse, and Sexual Abuse. The reporting strategies questionnaire was reformed according to the study.

Before doing actual survey, a pilot study (as shown in table 3 by alpha Cronbach's Reliability testing) was done on a randomly selected sample of 20 students of a private college. The data was analyzed by using the Statistical Package for Social Sciences (SPSS) version 20.0.

Results 


\begin{tabular}{|c|c|}
\hline Variables & Percentages (\%) \\
\hline \multicolumn{2}{|c|}{ SEX } \\
\hline Male & 26.6 \\
\hline Female & 74.4 \\
\hline \multicolumn{2}{|c|}{ AGE } \\
\hline $\begin{array}{l}>20 \text { and } \\
<22 \text { years }\end{array}$ & 18.5 \\
\hline $\begin{array}{l}>22 \text { and } \\
<25 \text { years }\end{array}$ & 14.4 \\
\hline \multicolumn{2}{|c|}{ INSTITUTE } \\
\hline Private & 46.6 \\
\hline Government & 53.4 \\
\hline \multicolumn{2}{|c|}{ RESIDENCY } \\
\hline Karachiites & 81.9 \\
\hline Non-Karachiites & 18.1 \\
\hline \multicolumn{2}{|c|}{ RELIGION } \\
\hline Muslim & 96.0 \\
\hline Non-Smoker & 2.8 \\
\hline
\end{tabular}

Table 2a: Crosstab (of Age and Type of Mistreatment)

\begin{tabular}{|c|c|c|c|c|c|c|c|}
\hline & & Age & & & & & \\
\hline & & 20 years & 21 years & 22 years & 23 years & 24 years & 25 years \\
\hline $\begin{array}{l}\text { Shouted At } \\
\text { You }\end{array}$ & $\%$ within Age & $13.8 \%$ & $15.2 \%$ & $23.4 \%$ & $14.0 \%$ & $6.9 \%$ & $20.7 \%$ \\
\hline $\begin{array}{l}\text { Belittled At } \\
\text { you }\end{array}$ & $\%$ within Age & $13.8 \%$ & $13.0 \%$ & $7.8 \%$ & $18.0 \%$ & $34.5 \%$ & $10.3 \%$ \\
\hline Extra Tasks & $\%$ within Age & $13.8 \%$ & $15.2 \%$ & $23.4 \%$ & $14.0 \%$ & $6.9 \%$ & $20.7 \%$ \\
\hline $\begin{array}{l}\text { Threatened } \\
\text { to fail }\end{array}$ & $\%$ within Age & $10.3 \%$ & $15.2 \%$ & $15.6 \%$ & $16.0 \%$ & $10.3 \%$ & $24.1 \%$ \\
\hline $\begin{array}{l}\text { Negative } \\
\text { Marks }\end{array}$ & $\%$ within Age & $20.7 \%$ & $10.9 \%$ & $14.1 \%$ & $4.0 \%$ & $10.3 \%$ & $3.4 \%$ \\
\hline False Credits & $\%$ within Age & $10.3 \%$ & $23.9 \%$ & $21.9 \%$ & $18.0 \%$ & $20.7 \%$ & $20.7 \%$ \\
\hline $\begin{array}{l}\text { Hit or } \\
\text { Pushed }\end{array}$ & $\%$ within Age & $11.7 \%$ & $3.8 \%$ & $2.4 \%$ & $1.0 \%$ & $2.0 \%$ & $20.7 \%$ \\
\hline $\begin{array}{l}\text { Threatened } \\
\text { to harm }\end{array}$ & $\%$ within Age & $3.4 \%$ & $6.5 \%$ & $3.1 \%$ & $4.0 \%$ & $6.9 \%$ & $10.3 \%$ \\
\hline $\begin{array}{l}\text { Sexual } \\
\text { Harassment }\end{array}$ & $\%$ within Age & $6.9 \%$ & $6.5 \%$ & $9.4 \%$ & $8.0 \%$ & $20.7 \%$ & $6.9 \%$ \\
\hline
\end{tabular}


Table 2b: Crosstab (of Gender and Type of Mistreatment)

\begin{tabular}{|l|l|l|}
\hline \multirow{2}{*}{} & \multicolumn{2}{|c|}{ Gender } \\
\cline { 2 - 4 } Shouted At You \% within Gender & $18.3 \%$ & FEMALE \\
\hline Belittled At you \% within Gender & $13.3 \%$ & $8.1 \%$ \\
\hline Extra Tasks \% within Gender & $20.0 \%$ & $9.7 \%$ \\
\hline Threatened to fail \% within Gender & $20.0 \%$ & $17.3 \%$ \\
\hline Negative Marks \% within Gender & $21.7 \%$ & $14.6 \%$ \\
\hline False Credits \% within Gender & $15.0 \%$ & $17.8 \%$ \\
\hline Hit or Pushed \% within Gender & $23.3 \%$ & $18.9 \%$ \\
\hline Threatened to harm \% within Gender & $38.3 \%$ & $42.9 \%$ \\
\hline Sexual Harassment \% within Gender & $6.9 \%$ & $46.5 \%$ \\
\hline
\end{tabular}

Table 2c: Crosstab (of Institute and Type of Mistreatment)

\begin{tabular}{|l|l|l|}
\hline \multirow{2}{*}{} & \multicolumn{2}{|c|}{ Gender } \\
\cline { 2 - 4 } & PRIVATE & GOVERNMENT \\
\hline Shouted At You \% within Institute & $10.3 \%$ & $21.8 \%$ \\
\hline Belittled At you \% within Institute & $8.6 \%$ & $19.5 \%$ \\
\hline Extra Task \% within Institute & $21.0 \%$ & $13.3 \%$ \\
\hline Threatened to fail \% within Institute & $22.4 \%$ & $20.3 \%$ \\
\hline Negative Marks \% within Institute & $37.9 \%$ & $15.8 \%$ \\
\hline False Credits \% within Institute & $14.7 \%$ & $22.6 \%$ \\
\hline Hit or Pushed \% within Institute & $23.3 \%$ & $42.9 \%$ \\
\hline Threatened to harm \% within Institute & $31.0 \%$ & $54.9 \%$ \\
\hline Sexual Harassment \% within Institute & $33.3 \%$ & $66.3 \%$ \\
\hline
\end{tabular}

Table 3: Reliability Statistics of Pilot testing of

Questionnaire.

\begin{tabular}{|l|l|}
\hline Cronbach's Alpha & $\begin{array}{l}\text { N of Items (Type of } \\
\text { Mistreatment) }\end{array}$ \\
\hline .859 & 9 \\
\hline
\end{tabular}

\section{Graph 1: Mistreatment Perceived by Participants (\%)}

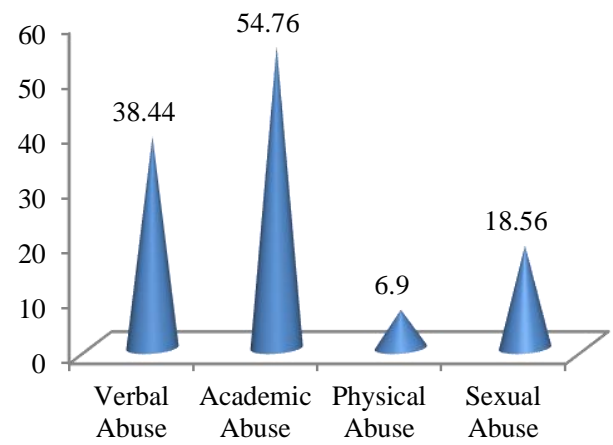

Total Mistreatmnt type (\%) 


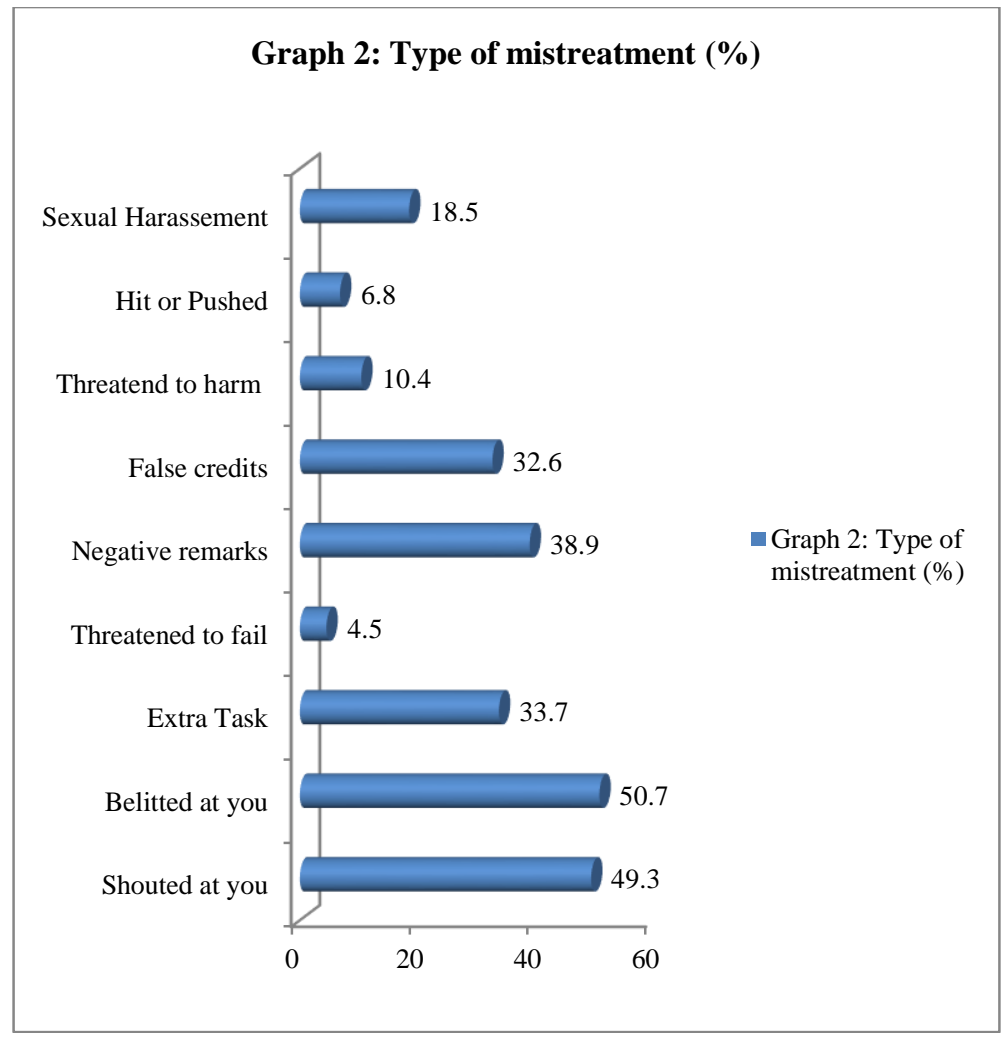

\section{Demographic Analysis:}

Among the 250 participants, the response rate was $100 \%$. The mean age was 22.44 years. Approximately half of the candidates were from private $(46.6 \%)$ and half were from government (53.4\%) medical college. About $81.9 \%$ of participants said that they were from Karachi, while $18.1 \%$ were not from Karachi but are studying here. $96 \%$ of the respondents were Muslims and the rest of the $2.8 \%$ were Non-Muslims (As shown in Table 1).

\section{Mistreatment Perceived by Participants:}

There was no missing response, the response rate was $100 \%$. Among those who had faced bullying or harassment, $38.44 \%$ reported that they had experienced verbal abuse, $54.76 \%$ reported academic abuse, $6.9 \%$ faced physical abuse, and $18.56 \%$ faced sexual abuse (as shown in Graph 1). However, the total percentage was estimated about $47.47 \%$.

\section{Types of Mistreatment:}

Nearly all the respondents reported experiencing at least one type of mistreatment or harassment from some source at some point during their time at medical colleges. About $47.47 \%$ of the abuse is seen in medical colleges of Karachi according to our study. The driving factor behind these types of abuses is markedly seemed to be psychological because most of the respondents were agreed as being shouted at $(49.3 \%)$ or belittled $(50.7 \%)$ publically. About $33.76 \%$ reported as being assigned an extra task and nearly the same about $38.9 \%$ reported as being tortured by giving negative remarks. The least frequent category was being hit or slapped $(6.80 \%)$ and threatened to harm $(10.46 \%)$. A large number of respondents reported that they were sexually abused $(18.56 \%)$, shown in Graph 2.
The cross tabulations of age, gender and institute with type of mistreatment have shown the marked significant, as shown in table $2 \mathrm{a}, 2 \mathrm{~b}$ and $2 \mathrm{c}$.

\section{Existence of Harassment Cell:}

A group of questions were asked about existing harassment cell at the medical college. Shockingly, all the participants negatively answered for the existence of harassment cell.

\section{Discussion}

According to Silver, $46.4 \%$ of students had been abused at some point during their time at medical schools. By the time they were seniors that number increased up to $80.6 \%$ (Major; 2013). After being familiarized to this meager issue of medical graduation, several scales and questionnaire were made to evaluate and identify the ratio of abuse as well as the cause. The Association of American Medical Colleges graduation questionnaires (AAMC GQs-2013) reported student mistreatment rates of $42.1 \%$ (Kassebaum and Cutler; 1998). Meanwhile, on the other side of the globe (specifically in UK), the General Medical Council (GMC2012) introduced a new indicator named 'Undermining'. It showed that $13 \%$ of respondents have been victims of bullying and harassment in their training post (GMC National Training Survey; 2013). However, Timm A. in 2014 surveyed on current undergraduate medical students at British medical school in which $43 \%$ of participants responded about their experiences of bullying and harassment (Timm; 2014). ). Until these researchers' studies, the UK had not previously conducted any quantitative study regarding these issues but they endorsed several valuable qualitative studies that voice the problematic aspects of students' socialization into medicine. They revealed 'Hidden Curriculum', which explains the set of influences that function at the level of organizational structure and culture. For example, they included implicit rules to survive the institution such as customs, rituals, and 
other aspects that are not accounted for enough (Lempp \& Seale; 2004) through hidden curriculum many students expressed professional dilemma, low self-esteem, and the negative impact on their confidence of students in clinical practice; that results from poor role-modeling, less attention, and irresponsibility. Studies elsewhere across the world about medical schools have upheld the findings of American studies; with schools in Chile, Finland, Israel, Japan, Pakistan, Germany, Saudi Arabia, Nigeria, and Canada reporting medical student abuse similar to American studies (Major; 2013). These studies have identified a similar resistance to eliminate the problem, even with an understanding that mistreatment is a "universally wrong tradition in medical culture" (Ogden, et al; 2005).

Our study was conducted to explore the extent of abuses faced by medical students of Karachi, together with the type and state of reporting systems in our institutes of such tendencies. Every candidate in the survey claimed experiencing one or more type of abuse faced at least once during his/her medical education. In the study overall results of the misconduct were found to be $47.47 \%$ .In our study the most frequent abuse reported by the candidates is the Academic abuse, which is reported to be encircling $54.76 \%$ of cases. The least was Physical abuse (6.9\%).Verbal and Sexual abuses were found to comprise $38.44 \%$ and $18.56 \%$, respectively. Our study's findings accedes previous researches done on same issue, which agrees that medical students are under a rock of harassment and bullying during their course of study. The stem causes of such issues are considered to be the specific perpetrator, organization and the environment of the college. As seen in our report $100 \%$ of respondents said that there is no reporting cell in their colleges. This is a prominent aspect to consider because it indicates that students cannot trust that their issue or complaint will be managed in a confidential manner.

Second and the most important factor is that students usually form their ideals when they first come to medical colleges. Teachers are mostly considered to be mentors, who students follow and rely on. After facing such cruel behavior by the mentors, students are no longer dedicated and provoked to learn, as they should be. A large number of candidates reported being hectored by the teachers on choosing medicine as their profession, as if they are not capable of this reputation. Another important finding was students are forced to follow the wills, and are threatened to be failed otherwise.

Most of the candidates reported an adverse effect of such events on their studies, motivation, commitments and even on their personalities. In spite of discovering harassment at such a large extent, almost none of the students were decisive ever to complain about such offense. The most important reason for such response by students was that students in our society accept to withstand such misconduct in the name of learning. Additionally, they are afraid of being labeled or misjudged by their teachers and colleagues. Candidates were also asked about the reporting/complaint cell in their institutions. As expected, there is not a single institution in our city with a complaint cell to benefit the students; that is very awful for the students.

\section{Conclusion}

Mistreatment and abuse is a common occurrence in our medical colleges and has found to be very adverse for the education, determination and self-confidence of our medical students. Mistreatment found in our study is considered a previous issue of emotional imbalance in students and lack of self-esteem. There is little chance for hope if bullying and harassment remains so common in any institution, because it causes students to feel them and become under pressure of cultural disobey of these specific issues besides their tough studies. Teachers should recognize their responsibilities and be as lenient and generous to the student as they can in order to produce cooperative doctors for our society. These mere issues are often not explored with great depth, which is detrimental because their impact is much worse.

Conflict of Interest

There is no Conflict of Interest in this study.

\section{Acknowledgement}

I (corresponding author) am obliged to Madam Zaufishan Quraishi and Advance Educational Institute of Research Centre for assessing this project. I am grateful to Madam Sadaf Ahmad, Sir Shamoon Noushad (AEIRC) and Dr Ata ur Rehman (HCMD) for that I don't have words but lots of prayers.

\section{References}

- Bowling, N. A., \& Beehr, T. A. (2006). Workplace harassment from the victim's perspective: a theoretical model and metaanalysis. Journal of Applied Psychology, 91(5), 998.

- Kassebaum, D. G., \& Cutler, E. R. (1998). On the culture of student abuse in medical school. Academic Medicine, 73(11), 1149-58.

- Lempp, H., \& Seale, C. (2004). The hidden curriculum in undergraduate medical education: qualitative study of medical students' perceptions of teaching. BMJ, 329(7469), 770-773.

- Major, Ajay. (16.3.2013). "To bully and be bullied: harassment and mistreatment in medical education." The virtual mentor: VM, 155-160.

- Ogden, P. E., Wu, E. H., Elnicki, M. D., Battistone, M. J., Cleary, L. M., Fagan, M. J., \& Wong, R. Y. (2005). Do attending physicians, nurses, residents, and medical students agree on what constitutes medical student abuse? Academic Medicine, 80(10), S80-S83.

- Rau, W., \& Durand, A. (2000). The academic ethic and college grades: Does hard work help students to" make the grade"? Sociology of Education, 19-38.

- Retrieved from: Pakistan Education Statistics 2010-2011 http://www.aepam.edu.pk/Files/EducationStatistics/PakistanEduc ationStatistics2010-11.pdf (accessed March, 2015)

- Retrieved from: GMC National Training Survey 2013 http://www.gmcuk.org/NTS_2013_autumn_report_undermining. pdf_54275779.pdf (Accessed March, 2015).

- Silver, H. K. (1982). Medical students and medical school. JAMA, 247(3), 309-310.

- Timm, A. (2014). 'It would not be tolerated in any other profession except medicine': survey reporting on undergraduates' exposure to bullying and harassment in their first placement year. BMJ open, 4(7), e005140. 